\title{
Insurance Coverage Policies for Pharmacogenomic and Multi-Gene Testing for Cancer
}

\author{
Christine Y. Lu ${ }^{1, *}$, Stephanie Loomer ${ }^{1}$, Rachel Ceccarelli ${ }^{1}$, Kathleen M. Mazor ${ }^{2}$, James Sabin ${ }^{3}$, \\ Ellen Wright Clayton ${ }^{4}$ (D), Geoffrey S. Ginsburg ${ }^{5}$ and Ann Chen $\mathrm{Wu}^{1}$ \\ 1 Precision Medicine Translational Research (PROMoTeR) Center, Department of Population Medicine, \\ Harvard Medical School and Harvard Pilgrim Health Care Institute, 401 Park Drive, Suite 401 East, \\ Boston, MA 02215, USA; stephanie_loomer@harvardpilgrim.org (S.L.); ceccare1@msu.edu (R.C.); \\ ann.wu@childrens.harvard.edu (A.C.W.) \\ 2 Meyers Primary Care Institute, A Joint Endeavor of the University of Massachusetts Medical School, \\ Reliant Medical Group and Fallon Health; 630 Plantation Street, Worcester, MA 01605, USA; \\ Kathy.Mazor@meyersprimary.org \\ 3 Departments of Population Medicine and Psychiatry, Harvard Medical School, Boston, MA 02115, USA; \\ jim_sabin@harvardpilgrim.org \\ 4 Center for Biomedical Ethics and Society, Vanderbilt University Medical Center, Nashville, TN 37232, USA; \\ ellen.clayton@vanderbilt.edu \\ 5 Duke Center for Applied Genomics and Precision Medicine, Duke University Medical Center, \\ Durham, NC 27710, USA; geoffrey.ginsburg@duke.edu \\ * Correspondence: christine_lu@harvardpilgrim.org; Tel.: +1-617-867-4989
}

Received: 16 April 2018; Accepted: 10 May 2018; Published: 16 May 2018

\begin{abstract}
Insurance coverage policies are a major determinant of patient access to genomic tests. The objective of this study was to examine differences in coverage policies for guideline-recommended pharmacogenomic tests that inform cancer treatment. We analyzed coverage policies from eight Medicare contractors and 10 private payers for 23 biomarkers (e.g., HER2 and EGFR) and multi-gene tests. We extracted policy coverage and criteria, prior authorization requirements, and an evidence basis for coverage. We reviewed professional society guidelines and their recommendations for use of pharmacogenomic tests. Coverage for KRAS, EGFR, and BRAF tests were common across Medicare contractors and private payers, but few policies covered PML/RARA, CD25, or G6PD. Twelve payers cover at least one multi-gene test for nonsmall cell lung cancer, citing emerging clinical recommendations. Coverage policies for single and multi-gene tests for cancer treatments are relatively consistent among Medicare contractors despite the lack of national coverage determinations. In contrast, coverage for these tests varied across private payers. Patient access to tests is governed by prior authorization among eight private payers. Substantial variations in how payers address guideline-recommended pharmacogenomic tests and the common use of prior authorization underscore the need for additional studies of the effects of coverage variation on cancer care and patient outcomes.
\end{abstract}

Keywords: pharmacogenomics; multi-gene testing; cancer; insurance coverage; tumor markers

\section{Introduction}

"Personalized medicine" is often described as providing "the right patient with the right drug at the right dose at the right time" [1]. Genomic tests are increasingly being used in clinical care to tailor treatment [2]. Approximately $\$ 5$ billion was spent on genomic testing in 2010; expenditures are projected to reach $\$ 25$ billion by 2021 [3]. As of 7 May 2018, there are over 54,538 tests for 
11,169 conditions, 16,415 genes, and 506 laboratories according to the National Institutes of Health's Genetic Testing Registry.

Genomic tests may identify individuals at risk of having a toxic response to a drug, thereby minimizing drug-related adverse events and associated costly consequences such as hospital admissions [4]. For example, pharmacogenomic tests for $H L A-B^{*} 1502$ can prevent potentially fatal carbamazepine-induced Stevens-Johnson syndrome. Pharmacogenomics tests can also identify individuals likely to respond to an intervention if molecular markers of therapeutic response are identified [5]. Examples include testing for epidermal growth factor receptor (EGFR) to determine the use of erlotinib in advanced nonsmall cell lung cancer (NSCLC), and KRAS testing to determine the use of cetuximab in advanced colorectal cancer. To aid clinical decision-making, the Centers for Disease Control and Prevention (CDC) has categorized genomic tests by level of evidence based on the Food and Drug Administration (FDA) labeling information, clinical practice guidelines, and systematic reviews [6]. This system defines about 50 genomic tests with sufficient evidence for clinical implementation (e.g., KRAS and human epidermal growth factor receptor 2 (HER2) tests to inform use of cetuximab in colorectal cancer and lapatinib in breast cancer, respectively).

At present, single gene tests cost about $\$ 200$ whereas multi-gene panels are available for $\$ 600$ [7]. Inter-related factors at the provider (e.g., specialty, training), patient (e.g., preferences), and health system (e.g., health insurance) levels affect patient access to genomic tests and related services [8]. Insurance coverage policies and levels of patient cost-sharing are major factors that influence who gets tested, screened, or treated, and when and which specific test is received [9-12]. To date, there has been a dearth of research on access to genomic tests. The objective of this study was to examine insurance coverage policies for guideline-recommended pharmacogenomic tests informing cancer treatment in order to identify potential access issues. We also sought to determine whether coverage policies are consistent with major clinical guidelines.

\section{Methods}

\subsection{Pharmacogenomic and Multi-Gene Tests for Cancer}

The CDC Office of Public Health Genomics (PHG) categorizes genomic tests by level of evidence based on the FDA labeling information, clinical practice guidelines, and systematic reviews $[6,13]$. This system defines 'tier-1' genomic tests as those that have a base of synthesized evidence that supports implementation in practice. We selected non-hereditary cancer-related pharmacogenomic tests for this study (Table 1). Because some of these tumor markers are now part of multi-gene tests, we also reviewed coverage policies for multi-gene panels that may govern access to tests for these biomarkers. The multi-gene panels we included are, however, not in the CDC's tier- 1 category at the time of the study. We did not include noncancer related multi-gene tests even if they were mentioned in some coverage policies as they are beyond the scope of this study. Whole genome sequencing and whole exome sequencing, which cover a large range of genes for noncancer indications, were not included in this study.

\subsection{Guidelines Search and Data Extraction}

We also reviewed publicly available guidelines from major professional societies and used them as a framework for examining coverage policies. The key evidence sources [6] that we included were: CDC's PHG and Evaluation of Genomic Applications in Practice and Prevention (EGAPP), National Cancer Institute (NCI), National Comprehensive Cancer Network (NCCN), American Society of Clinical Oncology (ASCO), Center for Medical Technology Policy (CMTP), Blue Cross Blue Shield Association Technology Evaluation Center (BCBSA TEC has recently been replaced by Evidence Street), American College of Medical Genetics and Genomics (ACMG), Agency for Healthcare Research and Quality (AHRQ), and the United Kingdom's National Institute for Health and Clinical Excellence (NICE). Search terms to identify relevant guidelines included: biomarker names, molecular profiling, 
multi-gene, and panel(s). We extracted the following information in August 2017 from the guidelines if the guideline recommended a pharmacogenomic test, the criteria, and the evidence basis for recommendation. Additionally, we extracted recommendations for multi-gene testing including suggested indications, for comparison with existing coverage policies mentioning multi-gene testing.

Table 1. Study drugs and pharmacogenomic and multi-gene tests.

\begin{tabular}{|c|c|c|c|}
\hline Biomarker & Drug Name & Condition & FDA Drug Approval Date \\
\hline \multirow[t]{2}{*}{ KRAS } & Cetuximab & Metastatic colorectal cancer & $2 / 12 / 2004$ \\
\hline & Panitumumab & Metastatic colorectal cancer & $9 / 27 / 2006$ \\
\hline \multirow[t]{5}{*}{ HER2 } & Trastuzumab & Gastroesophageal junction adenocarcinoma & $9 / 25 / 1998$ \\
\hline & Trastuzumab & Invasive breast cancer & 9/25/1998 \\
\hline & Pertuzumab & Invasive breast cancer & $6 / 8 / 2012$ \\
\hline & Ado-trastuzumab emtansine & Metastatic breast cancer & $2 / 22 / 2013$ \\
\hline & Lapatinib & Advanced or metastatic breast cancer & $3 / 13 / 2007$ \\
\hline \multirow[t]{3}{*}{$B R A F$} & Trametinib & Unresectable or metastatic melanoma & $5 / 29 / 2013$ \\
\hline & Dabrafenib & Unresectable or metastatic melanoma & $5 / 29 / 2013$ \\
\hline & Vemurafenib & Unresectable or metastatic melanoma & $8 / 17 / 2011$ \\
\hline \multirow[t]{2}{*}{ EGFR } & Afatinib & Metastatic Nonsmall cell lung cancer & $7 / 12 / 2013$ \\
\hline & Erlotinib & Metastatic Nonsmall cell lung cancer & $11 / 18 / 2004$ \\
\hline$A L K$ & Crizotinib & Nonsmall cell lung cancer & $8 / 26 / 2011$ \\
\hline \multirow{4}{*}{$B C R-A B L 1$} & Dasatinib & Chronic myeloid leukemia/Acute lymphoblastic leukemia & $6 / 28 / 2006$ \\
\hline & Imatinib & Chronic myeloid leukemia/Acute lymphoblastic leukemia & $5 / 10 / 2001$ \\
\hline & Bosutinib & Chronic Myeloid Leukemia & $9 / 4 / 2012$ \\
\hline & Nilotinib & Chronic Myeloid Leukemia & $10 / 29 / 2007$ \\
\hline c-Kit protein & Imatinib & Gastrointestinal stromal tumors & $5 / 10 / 2001$ \\
\hline PDGFR & Imatinib & Myelodysplastic/Myeloproliferative diseases & $5 / 10 / 2001$ \\
\hline CD20 & Tositumomab & Non-Hodgkin's lymphoma & $6 / 27 / 2003$ \\
\hline G6PD & Rasburicase & Leukemia, lymphoma & $7 / 12 / 2002$ \\
\hline CD25 & Denileukin diftitox & Cutaneous T-cell lymphoma & $2 / 05 / 2009$ \\
\hline PML/RARA & Arsenic trioxide & Acute promyelocytic leukemia & $9 / 25 / 2000$ \\
\hline \multicolumn{3}{|c|}{ Cancer Related Multi-Gene Tests } & CPT Code* \\
\hline \multicolumn{3}{|c|}{$\begin{array}{l}\text { Targeted genomic sequence analysis of } 5-50 \text { genes for solid tumors (e.g., ALK, BRAF, CDKN2A, EGFR, ERBB2, KIT, } \\
\text { KRAS, NRAS, MET, PDGFRA, PDGFRB, PGR, PIK3CA,PTEN, and RET) }\end{array}$} & 81445 \\
\hline \multicolumn{3}{|c|}{$\begin{array}{l}\text { Targeted genomic sequence analysis of 5-50 genes for hematologic malignancies (e.g., BRAF, CEBPA, DNMT3A, } \\
\text { EZH2, FLT3, IDH1, IDH2, JAK2, KRAS, KIT, MLL, NRAS, NPM1, and NOTCH1) }\end{array}$} & 81450 \\
\hline \multicolumn{3}{|c|}{$\begin{array}{l}\text { Targeted genomic sequence analysis of } 51 \text { or greater genes for solid tumors or hematologic malignancies (e.g., ALK, } \\
\text { BRAF, CDKN2A, CEBPA, DNMT3A,EGFR, ERBB2,EZH2, FLT3, IDH1, IDH2, JAK2, KIT, KRAS, MLL, NPM1, NRAS, } \\
M E T, \text { NOTCH1, PDGFRA, PDGFRB, PGR, PIK3CA, PTEN, and RET) }\end{array}$} & 81455 \\
\hline
\end{tabular}

* All Current Procedural Terminology (CPT) codes come from the American Medical Association [14]. FDA-Food and Drug Administration.

\subsection{Medicare Contractors and Private Payers}

Medicare is a public, nationwide health insurance program for people who are 65 and older in the US. We included all eight Medicare contractors: Novitas, National Government Services (NGS), Cigna Government Services (CGS), First Coast, Noridian, Palmetto, Wisconsin Physicians Service Insurance Corporation (WPSIC), and Cahaba. Private health insurance is often offered through an employer or organization but can also be purchased by an individual. We purposively selected the top US private payers based on the US News \& World Report listing of largest third-party payers [15]: UnitedHealth, Blue Cross Blue Shield-Massachusetts (BCBSA-MA), Anthem, Aetna, Humana, Health Care Service Corporation (HCSC), Cigna, Highmark, and Independence Blue Cross (IBX). Together, these private payers cover care for about 182.3 million individuals across the US; membership estimates were derived from payer websites and Google searches. We also included Harvard Pilgrim Health Care (HPHC), a regional health plan serving the New England population; we included HPHC because this study is part of a larger project that includes a qualitative aim [16], which interviewed patients and providers from this regional health plan.

\subsection{Policy Search and Data Extraction}

For each payer, we searched for and reviewed coverage policies for 23 pharmacogenomic tests and cancer-related multi-gene tests (Table 1). Coverage policies were generally publicly accessible through the payer's website, related websites (e.g., Centers for Medicare and Medicaid Services, CMS), and/or using search engines (Google). We searched for biomarker and drug names and key terms including genetic, gene, pharmacogenomics, biomarker, genomic, multi-gene, panel(s), sequencing, molecular profiling, and related Current Procedure Terminology (CPT) codes (e.g., 81275 for KRAS; three targeted 
sequencing CPT codes: 81445,81450 , and 81455$)$. We reviewed and extracted the following features from identified documents: policy name and date; whether the policy covers the test; criteria for coverage e.g., medical condition; requirements for prior authorization; evidence basis for coverage; and CPT codes. Reimbursement of a genetic test subject to prior authorization is only permitted if a physician requests and obtains prior approval from the payer. Prior authorization is commonly used to manage utilization and costs for medical services and procedures and medications [17]. Our search for single gene tests was last updated in April 2017 and in December 2017 for multi-gene tests. We verified extracted information of coverage policies with six payers by sending them data extraction tables of publicly available policies to ensure accurate interpretation.

\section{Results}

\subsection{Biomarker-Related Coverage Policies}

Guidelines for single gene tests are generally in consensus; thus, we present our findings on the relevant coverage policies. Table 2 summarizes Medicare contractor and private payer coverage policies identified for pharmacogenomic tests guiding cancer treatments, including both the number of policies that cover the tests (one test may be included in multiple policies) and number of payers that cover the tests (regardless of how many policies included the test). Policies identified were dated from August 2015 until February 2017. We did not identify any Medicare national coverage determinations for study biomarkers. Across eight Medicare contractors, KRAS, BRAF, and EGFR were the most commonly covered single gene tests; six contractors covered testing for $K R A S$, while four contractors covered testing for $B R A F$ and EGFR. Across 10 private payers, KRAS, EGFR, BRAF, and ALK were the most commonly covered single gene tests; nine payers covered testing for KRAS, EGFR, and $A L K$, and eight covered testing for BRAF.

There were differences across payers in terms of the presence of coverage policies for the specific pharmacogenomic tests included in the study, the content (e.g., covered indications), use of prior authorization requirements, and the evidence base cited (Table 2). Six private payers required prior authorization for single gene tests. The most common cited sources of references for coverage included: NCCN, ASCO, NCI, BCBSA TEC, and AHRQ. Evidence considered by payers for coverage decision making included randomized controlled trials and other study types, such as systematic reviews and cohort studies. The CPT codes specified by both Medicare and private payers were similar and included codes specific to biomarker testing and more general testing codes.

\subsection{Multi-Gene Tests Related Guidelines}

Few professional society guidelines were identified that specifically related to cancer multi-gene tests. Table 3 summarizes recent clinical recommendations for multi-gene testing. We identified substantial variation in the guidelines studied here. Evidence cited by these guidelines also differed such that no guidelines cited the same studies.

The guidelines that recommended multi-gene tests were NCCN [18], CMTP [19], ASCO [20], and ACMG [21], with NCCN and CMTP specifically recommending the tests for NSCLC. The CMTP also recommended such tests for other conditions including rare, uncommon, or stage IV solid tumors, e.g., lung and pancreatic cancers. These guidelines were largely based on small/medium sized observational studies, ranging from 31 to 2158 participants in each study [20,22-37]. Blue Cross Blue Shield Association TEC [38] and United Kingdom's NICE [39] did not recommend multi-gene testing in clinical practice; both guidelines, however, were published in 2013, earlier than other guidelines. Blue Cross Blue Shield Association TEC cited four studies for five cancer indications, concluding that compelling evidence of clinical utility was not available for multi-gene testing and issues still exist which need attention, including varying approaches to the interpretation of multi-gene testing. NICE assessed multi-gene testing for detecting EGFR mutation in adults with locally advanced or metastatic NSCLC and concluded that there is insufficient data on clinical utility 
and cost-effectiveness [39]. All guidelines recognized the potential of multi-gene testing but also acknowledged the need for additional research on clinical utility of such tests in different conditions. 
Table 2. Coverage policies for pharmacogenomic tests guiding cancer treatments by Medicare contractors $(n=8)$ and private payers $(n=10)$.

\begin{tabular}{|c|c|c|c|c|c|c|c|c|c|c|}
\hline & \multicolumn{2}{|c|}{ Number of Policies that Mention \& Cover the Test } & \multicolumn{2}{|c|}{ Number of Insurers that Cover the Test } & \multicolumn{2}{|c|}{ Covered Conditions } & \multicolumn{2}{|c|}{ Key References Cited in Coverage Policies } & \multicolumn{2}{|c|}{ CPT Codes Specified in Policies } \\
\hline & Medicare & Private & Medicare & Private & Medicare & Private & Medicare & Private & Medicare & Private \\
\hline KRAS & 6 & 12 & 6 & 9 & $\begin{array}{c}\mathrm{mCRC}^{3} \\
\mathrm{NSCLC} \\
\mathrm{CML} \\
\mathrm{ALL}\end{array}$ & $\begin{array}{c}\text { mCRC }^{3} \\
\text { Adeno- } \\
\text { carcinoma } \\
\text { NSCLC }\end{array}$ & $\begin{array}{c}\text { EGAPP; FDA; NCCN; } \\
\text { ASCO; } \\
\text { AHRQ; AMA; } \\
\text { USPSTF; CDC; } \\
\text { Palmetto }\end{array}$ & $\begin{array}{l}\text { BCBSA TEC; } \\
\text { EGAPP; ASCO; } \\
\text { NCCN; ACG; } \\
\text { CAP TEC }\end{array}$ & $\begin{array}{l}81275-276 \\
81311 \\
81405-406\end{array}$ & $\begin{array}{c}81275-276^{2} \\
81405\end{array}$ \\
\hline HER2 & 1 & 6 & 1 & 6 & $\begin{array}{c}\text { Breast cancer }{ }^{3} \\
\quad \text { Gastric } \\
\text { adenocarcinoma }\end{array}$ & $\begin{array}{c}\text { Breast cancer }{ }^{3} \\
\text { Gastric } \\
\text { adenocarcinoma } \\
\text { NSCLC }\end{array}$ & $\begin{array}{l}\text { NCCN; ASCO; } \\
\text { CDC; AHRQ; } \\
\text { AMA; USPSTF }\end{array}$ & $\begin{array}{c}\text { Hayes; NCCN; } \\
\text { NICE; ECRI; ASCO; } \\
\text { BCBSA TEC; } \\
\text { USPSTF; ACMG; } \\
\text { AHRQ } \\
\end{array}$ & None & $\begin{array}{c}83950 \\
88360-361^{1}\end{array}$ \\
\hline BRAF & 4 & 11 & 4 & 8 & $\begin{array}{c}\text { Melanoma }^{3} \\
\text { NSCLC } \\
\text { Hairy cell } \\
\text { leukemia } \\
\text { CRC } \\
\text { Brain cancer } \\
\text { Thyroid cancer } \\
\text { Ovarian/ } \\
\text { uterine cancer } \\
\end{array}$ & $\begin{array}{c}\text { Melanoma }^{3} \\
\text { NSCLC } \\
\text { GISTs } \\
\text { mCRC } \\
\text { Hairy cell } \\
\text { leukemia } \\
\text { Lynch syndrome }\end{array}$ & $\begin{array}{c}\text { EGAPP; FDA; NCCN; } \\
\text { ASCO; } \\
\text { AHRQ; AMA; } \\
\text { USPST; CDC; } \\
\text { Palmetto }\end{array}$ & $\begin{array}{c}\text { FDA; BCBSA TEC; } \\
\text { NCCN; AHRQ; } \\
\text { EGAPP }\end{array}$ & 81210 & $\begin{array}{l}81210^{2} \\
88363 \\
81406\end{array}$ \\
\hline EGFR & 4 & 12 & 4 & 9 & $\begin{array}{c}\text { NSCLC }^{3} \\
\text { Brain cancer }\end{array}$ & $\begin{array}{l}\text { NSCLC }^{3} \\
\text { CNS cancers }\end{array}$ & $\begin{array}{c}\text { EGAPP; FDA; NCCN; } \\
\text { ASCO; } \\
\text { AHRQ; AMA; } \\
\text { USPST; CDC; } \\
\text { Palmetto } \\
\end{array}$ & $\begin{array}{c}\text { ASCO; CAP; } \\
\text { NCCN; FDA; } \\
\text { CAP/IASLC/AMP }\end{array}$ & 81235 & $81235^{2}$ \\
\hline$A L K$ & 2 & 10 & 2 & 9 & NSCLC $^{3}$ & $\begin{array}{l}\text { NSCLC }^{3} \\
\text { Lymphoma } \\
\text { IMT }\end{array}$ & $\begin{array}{c}\text { EGAPP; FDA; NCCN; } \\
\text { ASCO; } \\
\text { AHRQ; AMA; } \\
\text { USPST; CDC; } \\
\text { Palmetto }\end{array}$ & $\begin{array}{l}\text { NCCN; NIH; } \\
\text { ASCO }\end{array}$ & None & $\begin{array}{c}81401^{1} \\
81479 \\
88271 \\
88274 \\
88291 \\
88367-368 \\
\end{array}$ \\
\hline BCR-ABL1 & 3 & 8 & 3 & 8 & $\begin{array}{l}\mathrm{CML}^{3} \\
\mathrm{ALL}^{3} \\
\mathrm{CMML}\end{array}$ & $\begin{array}{l}\mathrm{CML}^{3} \\
\mathrm{ALL}^{3}\end{array}$ & $\begin{array}{c}\text { EGAPP; FDA; NCCN; } \\
\text { ASCO; } \\
\text { AHRQ; AMA; } \\
\text { USPSTF; CDC; } \\
\text { Palmetto }\end{array}$ & $\begin{array}{l}\text { WHO; FDA; } \\
\text { NCCN; AHRQ; } \\
\text { NCI; ACS; } \\
\text { AMP; Hayes }\end{array}$ & $\begin{array}{c}81206-208 \\
81219 \\
81270 \\
81402-403\end{array}$ & $\begin{array}{c}88170 \\
88275 \\
81206-208^{2} \\
81401 \\
88271\end{array}$ \\
\hline
\end{tabular}


Table 2. Cont

\begin{tabular}{|c|c|c|c|c|c|c|c|c|c|c|}
\hline & \multicolumn{2}{|c|}{ Number of Policies that Mention \& Cover the Test } & \multicolumn{2}{|c|}{ Number of Insurers that Cover the Test } & \multicolumn{2}{|c|}{ Covered Conditions } & \multicolumn{2}{|c|}{ Key References Cited in Coverage Policies } & \multicolumn{2}{|c|}{ CPT Codes Specified in Policies } \\
\hline & Medicare & Private & Medicare & Private & Medicare & Private & Medicare & Private & Medicare & Private \\
\hline$c$-Kit & 2 & 3 & 2 & 3 & $\begin{array}{c}\text { GISTs }^{3} \\
\text { Melanoma } \\
\text { AML } \\
\text { ALL } \\
\text { MDS }\end{array}$ & $\begin{array}{c}\text { GISTs }^{3} \\
\text { Melanoma } \\
\text { AML } \\
\text { ALL } \\
\text { MDS }\end{array}$ & $\begin{array}{c}\text { EGAPP; FDA; NCCN; } \\
\text { ASCO; } \\
\text { AHRQ; AMA; } \\
\text { USPSTF; CDC; } \\
\text { Palmetto }\end{array}$ & NCCN & $81272-273$ & $\begin{array}{c}81272-273^{1} \\
88184\end{array}$ \\
\hline PDGFR & 1 & 1 & 1 & 1 & $\begin{array}{l}\text { MDS/MPN }{ }^{3} \\
\text { GISTs }\end{array}$ & $\begin{array}{c}\text { MDS/MPN }{ }^{3} \\
\text { GISTs }\end{array}$ & $\begin{array}{l}\text { AHRQ; AMA; } \\
\text { CDC; USPSTF }\end{array}$ & None & None & $\begin{array}{l}81314 \\
81404\end{array}$ \\
\hline CD20 & 0 & 2 & 0 & 2 & $\mathrm{~N} / \mathrm{A}$ & $\mathrm{NHL}^{3}$ & $\begin{array}{c}\text { AMA; } \\
\text { Palmetto }\end{array}$ & None & None & 88184 \\
\hline G6PD & 2 & 0 & 2 & 0 & None specified & N/A & AHRQ; CDC; USPSTF & N/A & $81247-249$ & N/A \\
\hline CD25 & 0 & 0 & 0 & 0 & N/A & N/A & $\mathrm{N} / \mathrm{A}$ & N/A & N/A & N/A \\
\hline PML/RARA & 2 & 3 & 2 & 2 & $\begin{array}{c}\text { Acute } \\
\text { promyelocytic } \\
\text { leukemia }\end{array}$ & $\begin{array}{c}\text { Acute } \\
\text { promyelocytic } \\
\text { leukemia }\end{array}$ & AHRQ; CDC; USPSTF & NCCN; FDA & $81315-316$ & $81315-316$ \\
\hline
\end{tabular}

${ }^{1}$ Most commonly used CPT code for biomarker testing; ${ }^{2}$ Specific CPT code for biomarker testing; ${ }^{3}$ Indicates FDA approved indication. All coverage counts based on medical coverage policies: last updated on 04/2017 for single gene tests; policies identified were dated from 08/2015 until 02/2017. Medicare contractors include Novitas, Noridian, Palmetto, Cahaba, Wisconsin Physicians Service Insurance Corporation (WPSIC), National Government Services (NGS), Cigna Government Services (CGS), and First Coast. Private payers include Harvard Pilgrim Health Care, United Healthcare, Anthem, Aetna, Cigna, Independence Blue Cross, Humana, Highmark, HCSC, and Blue Cross Blue Shield of Massachusetts. Abbreviations: CPT-Current Procedural Terminology. Conditions: ALL-acute lymphoblastic leukemia, AML-acute myeloid leukemia, CML-chronic myeloid leukemia, GISTs-gastrointestinal stromal tumors, IMT-inflammatory myofibroblastic tumor, MDS/MPN-myelodysplastic/myeloproliferative diseases, mCRC-metastatic colorectal cancer, NHL-Non-Hodgkin's lymphoma, and NSCLC-nonsmall cell lung cancer. References: ACG-American College of Gastroenterology, ACMG-American College of Medical Genetics and Genomics, ACS-American Cancer Society, AHRQ-Agency for Healthcare Research and Quality, AMA-American Medical Association, AMP-Association for Molecular Pathology, ASCO-American Society of Clinical Oncology, BCBSA TEC-Blue Cross Blue Shield Association Technology Evaluation Center, CAP TEC-College of American Pathologists Technology Evaluation Center, CDC-Centers for Disease Control and Prevention, ECRI-Emergency Care Research Institute, EGAPP-Evaluation of Genomic Applications in Practice and Prevention, IASLC-International Association for the Study of Lung Cancer, NCCN-National Comprehensive Cancer Network, NCI-National Cancer Institute, NICE-National Institute for Health and Care Excellence, USPSTF-United States Preventive Services Task Force, and WHO-World Health Organization. 
Table 3. Multi-gene testing recommendations by Professional Society Guidelines.

\begin{tabular}{|c|c|c|c|c|}
\hline & Society, Published Year & Indications Mentioned & Criteria/Reasoning & References Cited \\
\hline \multirow{7}{*}{$\begin{array}{l}\text { Recommend Multi-gene } \\
\text { Testing }\end{array}$} & ACMG, 2013 & None specified & $\begin{array}{l}\text { Targeted multi-gene testing is recommended for genetically heterogeneous } \\
\text { disorders and oncology applications. By limiting the content of the test to just the } \\
\text { regions relevant to a given disease, the resulting data usually have higher } \\
\text { analytical sensitivity and specificity for detecting mutations. }\end{array}$ & $\mathrm{NIH}$, College of American Pathologists \\
\hline & \multirow{3}{*}{ ASCO, 2015} & \multirow{3}{*}{ None specified } & $\begin{array}{l}\text { Testing option recommendations: } \\
\text { - Multi-gene testing may be efficient in circumstances that require evaluation } \\
\text { of multiple high-penetrance genes of established clinical utility } \\
\text { - Panel testing may identify mutations in genes associated with cancer risks } \\
\text { and mutations in high-penetrance genes } \\
\text { - Somatic mutation profiling can identify driver mutations in the cancer that } \\
\text { could serve as treatment targets }\end{array}$ & \multirow{3}{*}{$\begin{array}{l}\text { NIH, Cigna, observational study }(n=194 \text { and } \\
\text { 586), cross-sectional study }(n=2158) \text {, online } \\
\text { surveys }(n=225)\end{array}$} \\
\hline & & & $\begin{array}{l}\text { Tests being done to guide cancer treatment are often time sensitive and should } \\
\text { only include those tests that guide therapy. } \\
\text { Management of individuals/families with mutations in moderately penetrant } \\
\text { genes must include: }\end{array}$ & \\
\hline & & & $\begin{array}{l}\text { - A review of the literature so that family can determine the most appropriate } \\
\text { screening/prevention plan } \\
\text { Patients to have proper counseling, as the results of panel testing may not } \\
\text { always be straight-forward } \\
\text { - Challenges, risks, and benefits explained to patients prior to testing } \\
\text { Patient preferences should be included in decision making regarding the } \\
\text { most appropriate test }\end{array}$ & \\
\hline & \multirow[b]{2}{*}{ CMTP, 2015} & \multirow[b]{2}{*}{$\begin{array}{l}\text { NSCLC, advanced stage solid } \\
\text { tumors, hematologic } \\
\text { malignancies }\end{array}$} & $\begin{array}{l}\text { Testing of } 5 \text { or more genes is recommended with the following criteria: } \\
\text { - Must be clinically relevant as cited by NCCN or ASCO; OR } \\
\text { - is not more expensive than the cost of individual testing }\end{array}$ & \multirow[b]{2}{*}{ NCCN, Palmetto, review article } \\
\hline & & & $\begin{array}{l}\text { Testing of } 50 \text { or more genes is recommended with the following } \\
\text { criteria/indications: } \\
\text { - NSCLC } \\
\text { - Rare, uncommon, or stage IV solid tumors, e.g., lung and pancreatic cancers } \\
\text { Exhausted other treatment options (including unresponsiveness } \\
\text { of treatments) }\end{array}$ & \\
\hline & NCCN, 2017 & NSCLC & $\begin{array}{l}\text { Broader molecular profiling with the goal of identifying rare driver mutations for } \\
\text { which effective drugs may already be available, or to appropriately counsel } \\
\text { patients regarding availability of clinical trials. Broad molecular profiling is a key } \\
\text { component of the improvement of care of patients with NSCLC. }\end{array}$ & $\begin{array}{l}\text { ASCO, cohort study }(n=31) \text {, retrospective } \\
\text { observational study }(n=419)\end{array}$ \\
\hline
\end{tabular}


Table 3. Cont

Society, Published Year $\quad$ Indications Mentioned

Limited studies, poor study designs, plus a number of practical issues pertinent to
application of molecular marker profiling have not been sufficiently resolved for
clinical implementation. For example, the relative accuracy and precision of

different DNA sequencing methods are under investigation and may exhibit

variability secondary to training and experience of laboratories and personnel.

Optimal informatics methods to handle large amounts of sequencing data and

reconstruct them into clinically actionable information displays remain$$
\text { problematic. }
$$

Do Not Recommend
Multi-gene Testing

BCBSA TEC, 2013

None specifie

For non-Sanger sequencing based tests and for tests such as Therascreen EGFR

$\begin{array}{lll}\text { NICE, } 2013 & \text { NSCLC } & \begin{array}{l}\text { Pyro Kit and next generation sequencing, there is insuffic } \\ \text { therefore, no recommendations can be made on their use. }\end{array}\end{array}$

NCCN, systematic review and cost-effective
analysis

Years reflect most recent, available published guidelines mentioning or specific to molecular profiling/multi-gene testing.
References Cited

Two clinical trials $(n=68$ and 86$)$ bservational study $(n=460)$, methods study 


\subsection{Multi-Gene Tests Related Coverage Policies}

Table 4 summarizes coverage policies identified for cancer-related multi-gene tests. Policies identified were dated from April 2016 until December 2017. Eight Medicare contractors had 20 policies that mentioned and covered multi-gene tests. Specifically, six Medicare contractors covered multi-gene testing for NSCLC. Six of eight Medicare contractors also covered multi-gene tests for acute myelogenous leukemia (AML), myeloproliferative disease (MPD), and colorectal cancer (CRC). Palmetto's policies were frequently cited by other Medicare contractors. We did not find prior authorization requirements for multi-gene tests by Medicare contractors.

Six of ten private payers covered multi-gene testing for cancer in ten different policies. Six private payers specified coverage for NSCLC and two payers also covered multi-gene tests for myelodysplastic syndromes. In addition, Blue Cross Blue Shield provided coverage for many other indications including, but not limited to, colorectal cancer, gastrointestinal stromal tumors, and melanoma. IBX, HCSC, and Highmark, which all use eviCore, also provide coverage for colorectal cancer and melanoma. If a test was not covered, payers often cited limited clinical utility evidence as a justification and classified the test as "investigational/experimental." Seven private payers required prior authorization for any multi-gene tests for cancer that is covered.

Overall, policies from both private payers and Medicare contractors that covered multi-gene tests were based on clinical guidelines as well as studies of different types (including clinical trials, cohort studies, clinical validation studies, expert opinions, editorials, and reviews such as GeneReviews). Across both public and private payers, multi-gene testing for cancer is most commonly covered for NSCLC, which is consistent with recommendations from NCCN, the predominant guideline for cancer. Payers varied in their coverage of multi-gene testing for other cancers, which reflects the fact that guidelines vary in their recommendations for the use of multi-gene tests in other cancers (Table 3).

Table 4. Coverage policies for cancer related multi-gene tests by Medicare contractors $(n=8)$ and private payers $(n=10)$.

\begin{tabular}{lcc}
\hline & Medicare & Private \\
\hline Policy mentions \& covers at least one multi-gene test & 20 & 10 \\
\hline $\begin{array}{l}\text { Policy mentions \& does not cover any multi-gene tests or } \\
\text { covers only medically necessary genes within the panel }\end{array}$ & 3 & 6 \\
\hline Payers require prior authorization for testing & N/A & 7 \\
\hline Payers that cover at least one multi-gene test for NSCLC & 6 & 6 \\
\hline $\begin{array}{l}\text { Payers that cover at least one multi-gene test for conditions } \\
\text { other than NSCLC }\end{array}$ & Acute myelogenous leukemia \\
\hline & $\begin{array}{c}\text { CRC } \\
\text { MPD }\end{array}$ & 5 \\
Novered conditions & FDA, NCCN, WHO, Palmetto & $\begin{array}{c}\text { MPD } \\
\text { Thryoid cancer } \\
\text { NSCLC } \\
\text { Others }\end{array}$ \\
\hline Key references cited & ACBSA TEC, ECRI, Hayes Inc, NCCN, NDA, ACOG, USPSTF, \\
\end{tabular}

All coverage counts based on medical coverage policies; last updated on 12/2017 for multi-gene tests; policies identified were dated from 04/2016 until 12/2017; Medicare contractors include First Coast, Cahaba, CGS, National Government Services, Noridian, Novitas, Palmetto, and Wisconsin Physicians Services Insurance Company; Private payers include Aetna, Blue Cross Blue Shield of Massachusetts (BCBS), Anthem, Cigna, Harvard Pilgrim Health Care, HCSC, Highmark, Humana, Independence Blue Cross, and United Healthcare. ${ }^{1}$ BCBS covers many indications including: Solid Tumor NGS Panel: B-Cell NHL, bladder urothelial carcinoma, breast cancer, cholangiocarcinoma, endometrial carcinoma, GI stromal tumor, glioma, medulloblastoma, melanoma, meningioma, neuroblastoma, rare tumors, stomach/esophageal cancer, T-cell NHL, acute myeloid leukemia, B-ALL, B-cell NHL, myelodysplasia, myeloproliferative diseases, T-ALL, and T-Cell NHL. Abbreviations: ACOG-American College of Obstetricians and Gynecologists; ACS-American Cancer Society; ANZHSN-Australia and New Zealand Horizon Scanning Network; CRC-colorectal cancer; MPD-myeloproliferative disease; SGO-Society of Gynecologic Oncology.

\section{Discussion}

Genomic tests are increasingly used in clinical care and the associated businesses are booming. Insurance coverage policies can help govern the use of available resources for the population and support access to clinically valuable testing [40]. This study focused on insurance policies 
for guideline-recommended pharmacogenomic tests for cancer, either as single or multi-gene tests. We found substantial variations in how payers cover and manage pharmacogenomic testing for single gene tests as well as multi-gene tests, with more variations among private payers than Medicare contractors. Private payers commonly use prior authorization for these tests. Finally, we found discrepancies among coverage policies and clinical guidelines for multi-gene tests.

Variations in coverage policies among payers for single gene tests were present even though the pharmacogenomic tests included in the study were recommended by major guidelines for clinical implementation based on evidence [6]. It is important to note, however, lack of explicit policies do not necessarily translate to barriers to access for these single gene tests because Medicare contractors and private payers often do not have policies for specific genomic tests. Our interview study found that some payers do not view policies as necessary when clinical benefits are clear because policy development is time and resource intensive [41]. Perhaps this is not out of the ordinary given that many nongenetic medical services do not have specific policies beyond general statements about "medical necessity."

Multi-gene testing is currently being used in clinical practice and could possibly be more widely used than single gene testing because of its potential to detect genomic alterations in hundreds of cancer-related genes. We found variations in coverage of multi-gene testing across private payers but relatively smaller variations among Medicare contractors. There are several possible explanations for observed variations. First, while two major guidelines recommend the use of multi-gene testing for NSCLC (including NCCN, the predominant guideline for cancer), one guideline does not recommend the use of multi-gene testing for NSCLC and two others do not specify an indication for testing. It is not surprising that six of 18 payers did not have policies for multi-gene tests for NSCLC. Coverage of multi-gene testing for other cancers is highly variable, which reflects the fact that guidelines vary in their recommendation for testing in other cancers. Second, there is limited evidence $[17,38,42]$ on the clinical utility of multi-gene tests. Evidence cited by guidelines differs such that no guidelines cite the same studies, possibly due to the availability of published studies at the time of the assessment. The limited evidence and lack of clinical consensus prevent payers from judging whether a multi-gene test meets payers' standards of medical necessity. The need for more research to generate evidence on clinical utility of multi-gene tests is widely recognized [17]. Third, payers' consideration of different study types and interpretation of evidence could lead to differences in coverage. Few randomized controlled trials assessed the clinical utility of multi-gene tests given the complexities of such tests. Payers that cover multi-gene tests for NSCLC based their policies on clinical guidelines as well as a wide range of studies beyond randomized controlled trials including clinical validation studies, cohort studies, editorials, and reviews [43]. Finally, insurance coverage decisions are complex and they are based on evidence (including clinical utility evidence, and analytic and clinical validity information) as well as nonscientific factors (e.g., needs of the membership and lab contracting considerations), which are not outlined in coverage policies [41].

Importantly, we found that eight of ten private payers require prior authorization for all genomic testing, including single and multi-gene tests, to review medical necessity. Prior authorization generally obligates physicians to provide information on clinical indication and to specify gene(s) to be tested and patients to receive genetic counseling before and after genetic testing. Prior authorization is used to address the concern that, because multi-gene tests include a large number of genes, there is lack of transparency relating to the genes included in the panel tests $[17,41,42]$. Payers may determine the multi-gene test to be 'investigational' based on the combination of genes included that vary in their clinical utility. This concern relates to apprehensions about the numerous variants of unknown significance that might be reported to physicians. Such information may change physicians' recommendation and influence patients' decision to seek care that may not be appropriate. In order to grapple with the exponential growth in the types of tests and their growing use, and the limited expertise in this complex field [41], payers employ laboratory benefit management (LBM) companies to manage prior authorization applications and test utilization. This has occurred in other sectors of 
health care, for instance, pharmacy benefit management. The use of prior authorization is not limited to those payers who have contracted with an LBM. Of the eight private payers that require prior authorization for single gene and/or multi-gene testing, two do not use an LBM.

Variations in coverage policies and prior authorization requirements among payers create confusion for patients and clinicians as to who has access to these tests and how they are used in clinical practice [16]. We have several recommendations to reduce confusion and coverage variations. First, understanding of payer coverage needs to be improved for genomic tests through ongoing, systematic analyses of coverage policies and structured reporting. Coverage policies have a significant role in determining patient access to genomic tests but, as demonstrated by our study, they are extremely complex. Payers present information differently in their policies; for instance, some include a range of genomic tests in the same policy and some may require use of specific test products (e.g., Cologuard, Therascreen for KRAS). Registries of coverage policies, such as our own registry and the TRANSPERS Payer Coverage Policy Registry [17], can provide an objective, structured tool for research to examine coverage policies across payers, diseases or tests. These studies could facilitate greater transparency in payer coverage decision-making, identify evidence gaps, and enhance patient access to proven genomic tests. In addition to coverage policies, our registry also captures valuable information on prior authorization and major clinical guidelines. While prior authorization can help ensure appropriate use of genomic tests, it can also affect access to tests. Furthermore, it is important to examine whether coverage policies are consistent with clinical guidelines. Maintaining and keeping this type of registry up-to-date is a major undertaking, as the policies, prior authorization requirements, and guidelines are updated as evidence accumulates and/or as demand from patients and clinicians for access to genomic tests increases. Second, a single agency with appropriate expertise to assess evidence for coverage decisions, such as Hayes Inc., could reduce variations in coverage across payers. For instance, coverage for cancer-related multi-gene testing by Medicare contractors is relatively consistent because other Medicare contractors often adopt Palmetto's assessments of genomic tests, whereas substantial variations exist among private payers as they make their coverage decisions and policies independently. In addition, the use of LBM companies by payers is rapidly expanding to meet the need for systemization of evidentiary review and automate updates to keep up with the deluge of data in the literature [41]. Finally, increased dialogue and sharing of information among payers could also create a more harmonious and uniform system.

The strength of our study is that it is one of the first to systematically analyze the coverage of guideline-recommended pharmacogenomic tests for cancer, either as single or multi-gene tests, as well as discrepancies among coverage policies and clinical guidelines. Nevertheless, this study has several limitations. First, we included all Medicare contractors but not state Medicaid programs (Medicaid programs provide health insurance to low-income citizens across the US). We included only 10 private payers; however, we deliberately selected the top private payers across the US that provide coverage for about 182.3 million individuals. We also included major guidelines available publicly; however, there are other sources used by payers that we do not subscribe to and are therefore not included in the study (e.g., Hayes Inc., Lansdale, PA, USA). Second, we focused on tumor markers for guiding cancer treatments and those that were classified by CDC as tier- 1 category. We did not attempt to examine insurance coverage for multi-gene tests unrelated to these tumor makers; thus, access to many multi-gene tests was beyond the scope of this study (e.g., multi-gene tests for Lynch Syndrome) [17]. Third, our analysis of published coverage policies did not aim to describe comprehensively the complexity of coverage decision making. There are inherent limitations of published coverage policies as these documents do not discuss all the factors that determine coverage, including judgment in the interpretation of evidence. Fourth, the FDA recently approved a next generation sequencing-based in vitro diagnostic test that can detect genetic mutations in 324 genes and two genomic signatures in solid tumors [44]. The CMS also finalized a national coverage determination for this next generation sequencing-based diagnostic test [45]. The FDA's approval and CMS coverage for this multi-gene test is a big step forward in genomic health care and could influence future coverage and utilization 
of multi-gene tests (for cancer and beyond). Finally, coverage policies do not directly translate to reimbursement (e.g., whether prior authorization for the individual patient is approved).

\section{Conclusions}

Genomic tests are increasingly used in clinical care and the associated businesses are booming. Insurance coverage policies can help govern the use of available resources for the population and support access to clinically valuable testing. Our findings of variations in how payers are addressing pharmacogenomic tests and the common use of prior authorization underscore the need for additional research into the impact of these variations on cancer care and outcomes. Ongoing systematic analyses of coverage policies and prior authorization requirements considering key clinical recommendations are needed to improve understanding of access to and use of genomic tests.

Author Contributions: C.Y.L. and A.C.W. conceived and designed the experiments; C.Y.L., S.L., and R.C. performed the experiments; C.Y.L., S.L., and R.C. analyzed the data; C.Y.L. and S.L. drafted the paper; all authors revised the paper for important content.

Acknowledgments: We are grateful to Caitlin Lupton for her administrative support. This research was supported by the National Human Genome Research Institute of the National Institutes of Health (Award Number R21HG008510). The content is solely the responsibility of the authors and does not necessarily represent the official views of the National Institutes of Health.

Conflicts of Interest: The authors have no conflicts of interest.

\section{References}

1. FDA. The Precision Medicine Paving the Way for Personalized Medicine: FDA's Role in a New Era of Medical Product Development; FDA: Silver Spring, MD, USA, 2013.

2. Towse, A.; Garrison, L.P., Jr. Economic incentives for evidence generation: Promoting an efficient path to personalized medicine. Value Health 2013, 16, S39-S43. [CrossRef] [PubMed]

3. United Health Center for Health Reform \& Modernization. Personalized Medicine: Trends and Prospects for the New Science of Genetic Testing and Molecular Diagnostics; United Health Center for Health Reform \& Modernization: Minnetonka, MN, USA, 2012.

4. Jorgensen, J.T. New era of personalized medicine: A 10-year anniversary. Oncologist 2009, 14, 557-558. [CrossRef] [PubMed]

5. Armstrong, K. Can genomics bend the cost curve? JAMA 2012, 307, 1031-1032. [CrossRef] [PubMed]

6. Dotson, W.D.; Douglas, M.P.; Kolor, K.; Stewart, A.C.; Bowen, M.S.; Gwinn, M.; Wulf, A.; Anders, H.M.; Chang, C.Q.; Clyne, M.; et al. Prioritizing genomic applications for action by level of evidence: A horizon-scanning method. Clin. Pharmacol. Ther. 2014, 95, 394-402. [CrossRef] [PubMed]

7. Centers for Medicare and Medicaid Services. Clinical Laboratory Fee Schedule; Centers for Medicare and Medicaid Services: Baltimore, MD, USA, 2017.

8. Shavers, V.L.; Brown, M.L. Racial and ethnic disparities in the receipt of cancer treatment. J. Natl. Cancer Inst. 2002, 94, 334-357. [CrossRef] [PubMed]

9. Meckley, L.M.; Neumann, P.J. Personalized medicine: Factors influencing reimbursement. Health Policy 2010, 94, 91-100. [CrossRef] [PubMed]

10. Hresko, A.; Haga, S.B. Insurance coverage policies for personalized medicine. J. Pers. Med. 2012, 2, 201-216. [CrossRef] [PubMed]

11. Cohen, J.; Wilson, A.; Manzolillo, K. Clinical and economic challenges facing pharmacogenomics. Pharmacogenom. J. 2013, 13, 378-388. [CrossRef] [PubMed]

12. Graf, M.D.; Needham, D.F.; Teed, N.; Brown, T. Genetic testing insurance coverage trends: A review of publicly available policies from the largest US payers. Pers. Med. 2013, 10, 235-243. [CrossRef]

13. Centers for Disease Control and Prevention. Public Health Genomics Knowledge Base; CDC: Atlanta, GA, USA, 2017.

14. American Medical Association. American Medical Association Current Procedural Terminology CPT 2017; AMA Press: Chicago, IL, USA, 2017.

15. Heilbrunn, E. Top health insurance companies. U.S. News \& World Report, 5 November 2014. 
16. Wu, A.C.; Mazor, K.M.; Ceccarelli, R.; Loomer, S.; Lu, C.Y. Access to guideline-recommended pharmacogenomic tests for cancer treatments: Experience of providers and patients. J. Pers. Med. 2017, 7, 17. [CrossRef] [PubMed]

17. Phillips, K.A.; Deverka, P.A.; Trosman, J.R.; Douglas, M.P.; Chambers, J.D.; Weldon, C.B.; Dervan, A.P. Payer coverage policies for multigene tests. Nat. Biotechnol. 2017, 35, 614-617. [CrossRef] [PubMed]

18. Ettinger, D.S.; Wood, D.E.; Aisner, D.L.; Akerley, W.; Bauman, J.; Chirieac, L.R.; D'Amico, T.A.; DeCamp, M.M.; Dilling, T.J.; Dobelbower, M.; et al. Non-small cell lung cancer, version 5.2017, NCCN clinical practice guidelines in oncology. J. Natl. Compr. Cancer Netw. 2017, 15, 504-535. [CrossRef]

19. Messner, D.A.; Conley, R.; Al Naber, J.; Simmons, J.; Johnson, M.; King, J. Initial Medical Policy and Model Coverage Guidelines for Clinical Next Generation Sequencing in Oncology; Center for Medical Technology Policy, Green Park Collaborative: Baltimore, MD, USA, 2015.

20. Robson, M.E.; Bradbury, A.R.; Arun, B.; Domchek, S.M.; Ford, J.M.; Hampel, H.L.; Lipkin, S.M.; Syngal, S.; Wollins, D.S.; Lindor, N.M. American Society of Clinical Oncology policy statement update: Genetic and genomic testing for cancer susceptibility. J. Clin. Oncol. 2015, 33, 3660-3667. [CrossRef] [PubMed]

21. Rehm, H.L.; Bale, S.J.; Bayrak-Toydemir, P.; Berg, J.S.; Brown, K.K.; Deignan, J.L.; Friez, M.J.; Funke, B.H.; Hegde, M.R.; Lyon, E.; et al. ACMG clinical laboratory standards for next-generation sequencing. Genet. Med. 2013, 15, 733-747. [CrossRef] [PubMed]

22. Green, R.C.; Berg, J.S.; Grody, W.W.; Kalia, S.S.; Korf, B.R.; Martin, C.L.; McGuire, A.L.; Nussbaum, R.L.; O'Daniel, J.M.; Ormond, K.E.; et al. ACMG recommendations for reporting of incidental findings in clinical exome and genome sequencing. Genet. Med. 2013, 15, 565-574. [CrossRef] [PubMed]

23. Drilon, A.; Wang, L.; Arcila, M.E.; Balasubramanian, S.; Greenbowe, J.R.; Ross, J.S.; Stephens, P.; Lipson, D.; Miller, V.A.; Kris, M.G.; et al. Broad, hybrid capture-based next-generation sequencing identifies actionable genomic alterations in lung adenocarcinomas otherwise negative for such alterations by other genomic testing approaches. Clin. Cancer Res. 2015, 21, 3631-3639. [CrossRef] [PubMed]

24. Stadler, Z.K.; Schrader, K.A.; Vijai, J.; Robson, M.E.; Offit, K. Cancer genomics and inherited risk. J. Clin. Oncol. 2014, 32, 687-698. [CrossRef] [PubMed]

25. Varadhachary, G.R.; Raber, M.N. Cancer of unknown primary site. N. Engl. J. Med. 2014, 371, 757-765. [CrossRef] [PubMed]

26. Kurian, A.W.; Hare, E.E.; Mills, M.A.; Kingham, K.E.; McPherson, L.; Whittemore, A.S.; McGuire, V.; Ladabaum, U.; Kobayashi, Y.; Lincoln, S.E.; et al. Clinical evaluation of a multiple-gene sequencing panel for hereditary cancer risk assessment. J. Clin. Oncol. 2014, 32, 2001-2009. [CrossRef] [PubMed]

27. Parsons, D.W.; Roy, A.; Plon, S.E.; Roychowdhury, S.; Chinnaiyan, A.M. Clinical tumor sequencing: An incidental casualty of the American College of Medical Genetics and Genomics recommendations for reporting of incidental findings. J. Clin. Oncol. 2014, 32, 2203-2205. [CrossRef] [PubMed]

28. Le Tourneau, C.; Kamal, M.; Tredan, O.; Delord, J.P.; Campone, M.; Goncalves, A.; Isambert, N.; Conroy, T.; Gentien, D.; Vincent-Salomon, A.; et al. Designs and challenges for personalized medicine studies in oncology: Focus on the SHIVA trial. Target. Oncol. 2012, 7, 253-265. [CrossRef] [PubMed]

29. Westwood, M.; Joore, M.; Whiting, P.; van Asselt, T.; Ramaekers, B.; Armstrong, N.; Misso, K.; Severens, J.; Kleijnen, J. Epidermal growth factor receptor tyrosine kinase (EGFR-TK) mutation testing in adults with locally advanced or metastatic non-small cell lung cancer: A systematic review and cost-effectiveness analysis. Health Technol. Assess 2014, 18, 1-166. [CrossRef] [PubMed]

30. Tung, N.; Battelli, C.; Allen, B.; Kaldate, R.; Bhatnagar, S.; Bowles, K.; Timms, K.; Garber, J.E.; Herold, C.; Ellisen, L.; et al. Frequency of mutations in individuals with breast cancer referred for BRCA1 and BRCA2 testing using next-generation sequencing with a 25-gene panel. Cancer 2015, 121, 25-33. [CrossRef] [PubMed]

31. Plon, S.E.; Cooper, H.P.; Parks, B.; Dhar, S.U.; Kelly, P.A.; Weinberg, A.D.; Staggs, S.; Wang, T.; Hilsenbeck, S. Genetic testing and cancer risk management recommendations by physicians for at-risk relatives. Genet. Med. 2011, 13, 148-154. [CrossRef] [PubMed]

32. Cardarella, S.; Ortiz, T.M.; Joshi, V.A.; Butaney, M.; Jackman, D.M.; Kwiatkowski, D.J.; Yeap, B.Y.; Janne, P.A.; Lindeman, N.I.; Johnson, B.E. The introduction of systematic genomic testing for patients with non-small-cell lung cancer. J. Thorac. Oncol. 2012, 7, 1767-1774. [CrossRef] [PubMed]

33. Dienstmann, R.; Serpico, D.; Rodon, J.; Saura, C.; Macarulla, T.; Elez, E.; Alsina, M.; Capdevila, J.; Perez-Garcia, J.; Sanchez-Olle, G.; et al. Molecular profiling of patients with colorectal cancer and matched targeted therapy in phase I clinical trials. Mol. Cancer Ther. 2012, 11, 2062-2071. [CrossRef] [PubMed] 
34. Cragun, D.; Radford, C.; Dolinsky, J.S.; Caldwell, M.; Chao, E.; Pal, T. Panel-based testing for inherited colorectal cancer: A descriptive study of clinical testing performed by a US laboratory. Clin. Genet. 2014, 86, 510-520. [CrossRef] [PubMed]

35. Tsimberidou, A.M.; Iskander, N.G.; Hong, D.S.; Wheler, J.J.; Falchook, G.S.; Fu, S.; Piha-Paul, S.; Naing, A.; Janku, F.; Luthra, R.; et al. Personalized medicine in a phase I clinical trials program: The MD Anderson Cancer Center Initiative. Clin. Cancer Res. 2012, 18, 6373-6383. [CrossRef] [PubMed]

36. Von Hoff, D.D.; Stephenson, J.J., Jr.; Rosen, P.; Loesch, D.M.; Borad, M.J.; Anthony, S.; Jameson, G.; Brown, S.; Cantafio, N.; Richards, D.A.; et al. Pilot study using molecular profiling of patients' tumors to find potential targets and select treatments for their refractory cancers. J. Clin. Oncol. 2010, 28, 4877-4883. [CrossRef] [PubMed]

37. Institute of Medicine; Board on Health Care Services; Committee on Standards for Developing Trustworthy Clinical Practice Guidelines. Clinical Practice Guidelines We Can Trust; National Academic Press: Washington, DC, USA, 2011.

38. BlueCross BlueShield Association. Special report: Multiple molecular testing of cancers to identify targeted therapies. Technol. Eval. Center Assess. Program Exec. Summ. 2013, 28, 1-2.

39. National Institute for Health and Care Excellence (NICE). EGFR-TK Mutation Testing in Adults with Locally Advanced or Metastatic Non-Small-Cell Lung Cancer; NICE: London, UK, 2013.

40. Phillips, K.A. Closing the evidence gap in the use of emerging testing technologies in clinical practice. JAMA 2008, 300, 2542-2544. [CrossRef] [PubMed]

41. Lu, C.Y.; Treadwell, S.; Mazor, K.M.; Wu, A.C. Payer decision making for pharmacogenetic tests: Preliminary results (PCN213). Value Health 2017, 20, A126. [CrossRef]

42. Trosman, J.R.; Weldon, C.B.; Kelley, R.K.; Phillips, K.A. Challenges of coverage policy development for next-generation tumor sequencing panels: Experts and payers weigh in. J. Natl. Compr. Cancer Netw. 2015, 13, 311-318. [CrossRef]

43. Dervan, A.P.; Deverka, P.A.; Trosman, J.R.; Weldon, C.B.; Douglas, M.P.; Phillips, K.A. Payer decision making for next-generation sequencing-based genetic tests: Insights from cell-free DNA prenatal screening. Genet. Med. 2017, 19, 559-567. [CrossRef] [PubMed]

44. US Food and Drug Administration. FoundationOne CDx-P170019. Available online: https://www. accessdata.fda.gov/cdrh_docs/pdf17/P170019a.pdf (accessed on 7 May 2018).

45. Center for Medicare and Medicaid Services. CMS Finalizes Coverage of Next Generation Sequencing Tests, Ensuring Enhanced Access for Cancer Patients. Available online: https://www.cms.gov/ Newsroom/MediaReleaseDatabase/Press-releases /2018-Press-releases-items/2018-03-16.html (accessed on 7 May 2018).

(c) 2018 by the authors. Licensee MDPI, Basel, Switzerland. This article is an open access article distributed under the terms and conditions of the Creative Commons Attribution (CC BY) license (http://creativecommons.org/licenses/by/4.0/). 